\title{
ЦИФРОВА СТРАТЕГІЯ ЯК СКЛАДНИК СОЦАЛЬНО- КОМУНІКАЦЙНОГО ПРОСТОРУ ЗАКЛАДУ ВИЩОЇ ОСВІТИ
}

\author{
Ольга Біличенко \\ доктор наук із соціальних комунікацій, професор, завідувач кафедри \\ української мови та літератури, \\ ДВНЗ «Донбаський державний педагогічний університет» \\ м. Слов'янськ, Україна \\ ORCID ID 0000-0002-9292-9938 \\ Olgabelichenko64@gmail.com
}

\begin{abstract}
Анотація. У статті висвітлено місце цифрової стратегії у функціонуванні соціальнокомунікаційного простору закладу вищої освіти. Автор обгрунтовує необхідність використання цифрових інструментів в університетському навчальному процесі, переходу до нових, цифрових моделей навчання. Цифровізація вищої освіти визначається як необхідна відповідь на суспільні виклики сьогодення. На основі аналізу проблем, що виникають у сфері вищої освіти, автор визначає низку завдань, виконання яких сприятиме процесам цифровізації вітчизняної університетської освіти. У статті розкриваються особливості соціальнокомунікаційного простору вищого навчального закладу. Автор детально аналізує його структуру та специфіку функціонування. В межах статті автор доводить необхідність розглядати соціально-комунікаційний простір вищого навчального закладу як різновид соціально-комунікаційного простору освіти в цілому. Автором доводиться необхідність розробки гнучкого соціально-комунікаційного простору 3 цифровим компонентом, орієнтованого на розвиток світу комунікаційних взаємовідносин в освітній системі.
\end{abstract}

Ключові слова: цифровізація; вища освіта; соціальні комунікації.

Постановка проблеми в загальному вигляді. В умовах модернізації та зростання значущості інформаційних технологій, інновацій комунікаційних каналів кардинально змінюється уявлення про сучасні суб’єкти освітньої сфери. Сучасний вищий навчальний заклад виступає базовим інститутом для створення принципово нових моделей комунікації. В умовах активізації інформаційного потоку метою його діяльності стає не тільки акумуляція, продукування, збереження та розповсюдження певної суми знань, а й забезпечення різних форм доступу до них незалежно від локації користувача.

У травні 2021 року було оприлюднено Проєкт Стратегії цифрового розвитку освіти, цифрових трансформацій і цифровізації, розроблений МОН та націлений на те, щоб створити єдину освітню екосистему. Стратегія націлена на те, щоб допомогти здобувачам освіти та педагогічним працівникам розвиватись, опановувати цифрові компетентності й мати постійний доступ до якісного цифрового контенту.

Професіоналізм педагога: теоретичні й методичні аспекти. Методичні матеріали до проєкту «Цифровий освітній простір: українсько-польський досвід». - Слов’янськ, 2021. 
Цифрова стратегія як складник соціально-комунікаційного простору закладу вищої освіти

Сучасні вищі навчальні заклади інтенсивно долучаються до єдиної комунікаційної системи суспільства, яке у свою чергу, динамічно взаємодіє 3 глобальним соціокультурним середовищем. Комунікаційні процеси у суспільстві призводять до створення соціально-комунікаційного простору вищих навчальних закладів.

Разом 3 тим, сучасний стан функціонування вищих навчальних закладів відзначається інтенсивним збільшенням власного соціально-комунікаційного простору, який характеризує сукупність інформації, інтелектуальних ресурсів, інформаційних технологій, комунікаційної інфраструктури і включає різні категорії суб'єктів. Соціально-комунікаційний простір - складова комунікаційного простору вищого навчального закладу.

В сучасних соціокультурних умовах на передній план виходить комунікаційний процес, який змінює особливості людського існування. Науковці зазначають, що з кінця XX століття зміна в засобах комунікації обумовила таке явище як глобалізація інформаційних процесів.

Аналіз останніх досліджень і публікацій. Сучасні науковці доходять висновку, що стрімке поширення інформації впливає на специфіку спілкування, а нові комунікаційні форми створюють нове соціальне й соціокультурне середовище. У межах цього простору здійснюються контакти між різними суб'єктами комунікації, створюючи суб'єкт-суб'єктні і суб'єктні відносини.

Дослідники зазначають, що особливості процесів комунікації закладів вищої освіти потребують складних моделей, що зумовлює необхідність зважати на вплив зовнішніх соціальних інститутів. Варто підкреслити, що сучасні українські заклади вищої освіти входять до складу єдиної комунікаційної системи суспільства. За допомогою процесів комунікації суспільство створює інформаційно-комунікаційний простір, що не має географічних чи територіальних обмежень, містить як зовнішню, так і внутрішню комунікацію різних рівнів.

Проблема використання інформаційно-комунікаційних (цифрових) технологій, створення цифрового освітнього середовища, цифровізація освітнього процесу знайшли відтворення в багаточисленних дослідженнях. На сьогодні вітчизняними й зарубіжними вченими напрацьовано значний обсяг матеріалу щодо цифровізації освіти. Концептуальні проблеми інформатизації та цифровізації освіти втілені в численних наукових розвідках М. Жалдак, А. Лазаревич, О. Овчарук, Д. Беррі, Д. Бретт, М. Варшавер, Д. Кларк, Дж. Романі. Дослідження різних аспектів цифрової культури як феномену інформаційного суспільства знайшли відображення в роботах Л. Гаврілової, I. Елінер, О. Карпенко, С. Черних.

() ДВНЗ «Донбаський державний педагогічний університет» 
Цифрова стратегія як складник соціально-комунікаційного простору закладу вищої освіти

Проте саме місце цифрового компоненту в соціально-комунікаційному просторі вищого навчального закладу практично залишається поза увагою дослідників.

Комунікаційний простір - це сфера, в якій здійснюється інформаційний обмін за допомогою комунікацій; простір, де протікає комунікативний процес. Дослідники визначають його як систему численних комунікативних зв'язків, що виникають між різними агентами комунікації, якими можуть виступати окремі люди, групи людей (великі та малі), соціальні інститути. Комунікаційний простір характеризується інтенсивністю і кількістю взаємодій та дистанцією між агентами комунікативної взаємодії. Соціально-комунікаційний простір вищого навчального закладу постає у вигляді складного багатоелементного утворення $\mathrm{i}$, в свою чергу, є структурним базисом комунікаційного простору.

Проблема простору пов'язана 3 осмисленням його змістовного наповнення. Так, наприклад, серед глобальних проблем інформаційної епохи В. Шейко (2001) виокремлює формування єдиного інформаційно-освітнього простору, який почав активно досліджуватися наукою з 90-х рр. XX ст. На думку автора, його формування здатне вирішити такі глобальні проблеми техногенної цивілізації, як освіта, виховання, зростання культурного рівня.

В комплексному осмисленні феномену комунікаційного простору i дослідженні його складових у вищому навчальному закладі ми скористалися роботами В. Ільганаєвої (2009), зокрема, дефініцією «соціокомунікаційний простір», яка методологічно наголошує на ролі комунікації в структуроутворенні соціального простору. Ми можемо спиратися на дослідження П. Бурд’є (2010), який найдокладніше розглянув поняття простору, уявивши його у формі багатовимірного простору, побудованого за принципами диференціації та поділу.

Формулювання цілей статті (постановка завдання). У зв'язку із тим, що сьогодні посилює позиції гуманістична освіта, з'являються задачі проєктування нового середовища як простору, адекватного сучасним потребам. Тому метою нашого дослідження $\epsilon$ спроба довести необхідність розробки гнучкого соціально-комунікаційного простору, орієнтованого не стільки на предметний світ, скільки на розвиток світу комунікаційних взаємовідносин в освітній системі.

Результати дослідження. Деякі дослідники визначають комунікаційний простір як систему комунікацій груп, що мають різні функції, статуси, потреби та цінності. У вищому навчальному закладі освіти комунікації першого рівня це викладачі та студенти в аудиторіях (процес передачі знань); комунікації 
Цифрова стратегія як складник соціально-комунікаційного простору закладу вищої освіти

другого рівня - це декани і студенти, студенти й диспетчерська, викладачі диспетчерська - деканати (процес організації передачі знань); комунікації третього рівня - викладачі - керівництво кафедрами та факультетами - ректорат (визначення змісту і технологій освіти); комунікації четвертого рівня: ректорат міністерство. Комунікація у вищому навчальному закладі забезпечує рух навчальної інформації в часі та просторі за допомогою документації не лише в паперовій формі, а й в цифровій завдяки розвиткові нових IКТ.

Спираючись на концепції інформаційного суспільства, які сформувалися у вітчизняній та зарубіжній науці, можна виокремити особливий соціальнокомунікаційний простір як сферу, в якій здійснюється інформаційний обмін за допомогою комунікацій; простір, де протікає комунікаційний процес.

Головною особливістю розвитку сучасного вищого навчального закладу України є розвиток його комунікаційного потенціалу. Сучасні вищі навчальні заклади, інтегруючи у світовий інформаційний простір, не можуть бути ефективними, конкурентоспроможними, не пропонуючи свої освітні послуги в міжнародному інформаційному просторі. Наразі у вищій школі комунікація посідає одне з найважливіших місць у формуванні та вдосконаленні освітнього процесу. Глобальні соціально-комунікаційні процеси дійсно активно впливають на сферу освіти, на процеси обміну наукової, освітньої та навчальної інформації не тільки між викладачами та студентами в рамках одного вищого навчального закладу, а й залученням до обміну інших.

У результаті теоретичного аналізу педагогічних та соціальнокомунікаційних досліджень соціально-комунікаційного простору можна зробити висновок, що комунікаційний простір визначається як система стилів педагогічного спілкування, типів педагогічних комунікацій, об'єднаних єдиною метою та педагогічною позицією щодо учасників освітнього процесу, яка впорядковує комунікативні функції освітньої системи (індивідуальні, групові й соціальні комунікації) та спрямована на створення сприятливих умов для всебічного розвитку особистості, іiі соціалізації, індивідуальній адаптації в соціальному середовищі.

Дослідники виокремлюють два рівні комунікації вищого навчального закладу:

1) первинно-документний рівень, на якому представлені документи суспільного використання з відповідними каналами. У вищому навчальному закладі - це документи, що супроводжують освітянську діяльність;

2) вторинно-документний або документографічний рівень, на якому представлені неопубліковані бібліографічні матеріали, бази машиночитаних даних, бібліографічні видання (канал рукописів, поліграфічний канал, канал

() ДВНЗ «Донбаський державний педагогічний університет» 
Цифрова стратегія як складник соціально-комунікаційного простору закладу вищої освіти

машиночитаних документів). Говорячи про комунікацію у вищому навчальному закладі, ми розуміємо їі як обмін навчальною інформацією, документацією по певних комунікаційних каналах за допомогою сучасних інформаційнокомунікаційних засобів вищого навчального закладу. Перспективи створення нових комунікативних засобів надзвичайні. Ті інформаційні потоки, що вже створені, привели до інформаційної залежності всіх сфер життя суспільства.

За визначенням В. Ільганаєвої (2009) соціально-комунікаційний простір це симбіоз природно-штучних зв'язків та реалій соціальних відносин, в основі яких лежать механізми формування людини, суспільства, соціального інтелекту. Соціально-комунікаційний простір проявляє властивості багаторівневості та нелінійності, багатосередовищності та підтримується їх динамічним розвитком, трансформацією носіїв комунікативних функцій, виконавців комунікативної дії і механізмами внутрішньо-системної взаємодії, таким чином забезпечуючи формування, розвиток соціального інтелекту, досягнення ним вищого рівня «колективного свідомого» як єдності високорозвинених «індивідуальних знань» членів суспільства.

Соціально-комунікаційний простір складають соціально-комунікаційні середовища, що представляють сукупність комунікаційних умов суспільства, які утворюються внаслідок формування великої кількості перетворених форм діяльності, що утворює смисли і результати якої безпосередньо передбачені для системи соціальної взаємодії.

Говорячи про простір, дослідники мають на увазі сукупність певним чином пов'язаних між собою умов, які можуть впливати на людину. В цьому випадку за смислом в самому понятті простору не передбачається включення в нього людини. Простір - форма буття матерії, що характеризує іiі протяжність, структурність, співіснування та взаємодію елементів в усіх матеріальних системах. Обмеження простору, за переконанням В. Ільганаєвої (2009) пов'язані 3 уявленнями про соціальний час та соціальний простір. Простір може існувати $\mathrm{i}$ незалежно від нього.

Комунікаційний простір - цей термін не рівнозначний комунікаційному середовищу: існуючи в одному й тому ж комунікаційному просторі, індивід може переходити з одного комунікаційного середовища в інше. Людина може перебувати одночасно в різних комунікаційних середовищах, наприклад, в комунікаційному середовищі віртуальної реальності (спілкування в мережі Інтернет, комп'ютерні ігри). І хоча ці середовища інколи надзвичайно різнорідні, індивідом вони сприймаються як єдине ціле. 
Цифрова стратегія як складник соціально-комунікаційного простору закладу вищої освіти

Сучасний вищий навчальний заклад виступає базовим інститутом для створення принципово нових моделей комунікації. В умовах активізації інформаційного потоку метою діяльності стає не тільки акумуляція, продукування, збереження та розповсюдження певної суми знань, а й забезпечення різних форм доступу до них, незалежно від локації користувача. Можна стверджувати, що вищі навчальні заклади перебувають на етапі інтенсивного формування нового інформаційно-освітнього середовища, де пріоритетними $є$ процеси обміну інформації з використанням новітніх цифрових технологій.

Цифровий сегмент соціально-комунікаційного простору має значний вплив на процеси комунікації у вищому навчальному закладі. В комунікаційному контексті освітній простір може розглядатися як сукупність освітніх умов соціалізації особистості, як суб'єкта освітнього процесу, а також як сукупність критеріїв і програм освітньої діяльності, які складають сферу систематизованого знання, об'єднаного на змістовому і структурному рівнях.

На основі вищезазначеного, структура комунікаційного простору вищого навчального закладу містить два основні компоненти: комунікаційне середовище й освітній простір, в межах яких комунікаційні процеси та цифрові структури забезпечують цілеспрямований обіг соціальної інформації та знань в просторово-часовому континуумі суспільства.

Вивчення цифрового складника між названими елементами системи у вищому навчальному закладі виявляє його функціональні властивості:

- забезпечення процесу передачі та обміну навчальною інформацією;

- наявність матеріального носія, за допомогою якого відбувається процес передачі навчальної інформації в часі й просторі;

- здатність бути каналом збору, накопичення, формування, розповсюдження інформації в часі й просторі;

- здатність бути засобом і результатом навчальної діяльності;

- сприяння процесу формування нових знань;

- забезпечення і підтримка процесів соціалізації;

- спрямування інформації, що забезпечується використанням інформаційно-комунікаційних технологій.

Таким чином, у комунікаційному просторі вищого навчального закладу функціонують чотири головні суб'єкти зі своїм статусом, інтересами, цінностями - держава, адміністрація вищого навчального закладу, викладачі та студенти.

Серед основних процесів комунікації виділяємо:

- комунікаційний процес навчання та викладання; 
Цифрова стратегія як складник соціально-комунікаційного простору закладу вищої освіти

- комунікаційний процес керування вищим навчальним закладом;

- комунікаційна діяльність його підрозділів;

- комунікаційні середовища вищого навчального закладу.

Ці процеси мають стати стратегічними в соціально-комунікаційному просторі вищого навчального закладу і грунтуватися на наступних принципах:

- єдності професійних цілей і завдань всіх учасників науково-освітнього процесу, різних підрозділів, незалежно від рівня їх інформатизації;

- системності, що передбачає збалансованість процесу інформатизації за напрямками та послідовність здійснюваних заходів;

- модульності - створення інформаційних систем різної складності, автономності та ступеня інформаційного забезпечення;

- технологічності, коли реальні економічні можливості університету відповідають функціям університету, кадровому потенціалу та заявленому рівню інформатизації;

- динамізму - відповідності рівня інформатизації науково-освітнього процесу інформаційним потребам, які швидко змінюються, i технічним можливостям їх задоволення.

У соціально-комунікаційному просторі вищого навчального закладу відбувається процес соціалізації особистості, цілі й форми якого окреслюються вимогами й очікуваннями суспільства та моніторяться державою. В межах соціально-комунікаційного простору здійснюється комунікація між різними суб'єктами інформації та комунікації, тобто функціонує структура суб'єктсуб'єктних та суб'єкт-об'єктних відносин. Складовими соціальнокомунікаційного простору вищого навчального закладу є: суб'єкти комунікації (студенти та професорсько-викладацький склад); засоби комунікації (інструменти та технології, що використовуються для передачі навчальної інформації, канал передачі); предмет комунікації та повідомлення, що його відображає (навчально-методична інформація); ефект комунікації (наслідки комунікаційної діяльності, що проявляються або у результаті, поведінці, або у внутрішньому стані, або у відносинах суб’єктів цієї комунікації).

Соціально-комунікаційний простір закладу вищої освіти може постійно змінюватися у зв'язку з виникненням нових засобів комунікації в навчальному процесі. Варто підкреслити, що під час комунікації, що здійснюється в межах соціально-комунікаційного простору, відбувається процес соціалізації особистості, цілі та форми якого визначає соціум. У такому середовищі комунікація стає своєрідним способом існування студентської молоді. Простір «Цифровий освітній простір: українсько-польський досвід». - Слов’янськ, 2021. 
Цифрова стратегія як складник соціально-комунікаційного простору закладу вищої освіти

науковці характеризують такими властивостями, як структурність, довжина, співіснування та взаємодія елементів у всіх матеріальних системах.

Цифровий складник соціально-комунікаційного простору закладу вищої освіти надзвичайно важливий для студентів, оскільки участь у комунікаційних процесах виступає як частина певної соціальної ролі і відповідає певному соціальному статусу. Оскільки заклад освіти завжди розумівся як найстаріший соціальний інститут, інструмент передачі соціального досвіду, можна розглядати його і як специфічне соціальне середовище соціалізації і специфічна форма комунікаційного простору. Соціально-комунікаційний простір вищого навчального закладу може розглядатися як різновид соціально-комунікативного простору освіти в цілому.

Висновки 3 дослідження і перспективи подальших розвідок у цьому напрямі. За нашим переконанням, соціально-комунікаційний простір вищого навчального закладу - це складний елемент соціальної реальності, що має свою структуру, містить суб'єктивно-об'єктивні відносини різних рівнів, має свій інформаційний зміст. В межах соціально-комунікаційного простору відбуваються процеси навчання, тобто передача знань, умінь та навичок, формальна організація процесу навчання; комунікації різного змісту та різного рівня в навчанні, визначення ролі, інтересів, потреб та ідеалів основних суб’єктів; електронно-документальний супровід навчання; впровадження нових IKT, які вдосконалюють та розширюють комунікацію. В процесі комунікації, що здійснюється у вищому навчальному закладі відбувається процес соціалізації особистості, цілі та форми якого визначаються соціумом та регулюються державою.

Подальше дослідження соціально-комунікаційного простору вищого навчального закладу відкриває перспективи поглибленого вивчення та виявлення факторів і тенденцій розвитку самого вищого навчального закладу. Складний процес комунікації виглядає як багатогранне утворення, яке визначається багатоканальністю i представляє собою взаємодію багатьох об’єктивних і суб'єктивних чинників.

\section{СПИСОК ВИКОРИСТАНИХ ДЖЕРЕЛ}

1. Буряк, В. Д. (2010). Комунікація і текстовий дискурс. Держава та регіони. Серія : Соціальні комунікації, 3, 4-7.

2. Гужва, В. М. (2019). Цифрова трансформація університетів. Східна Європа: економіка, бізнес та управління, 21, 597-604.

3. Єгорченкова, Н. Ю., Тесля, Ю. М., Хлевна, Ю. Л., \& К Кичань, О. М., $\quad$ (2020). Методологічні аспекти створення цифрового університету. Вісник Національного технічного університету «Харківський політехнічний інститут». Серія: Стратегічне управління, 
Цифрова стратегія як складник соціально-комунікаційного простору закладу вищої освіти

управління портфелями, програмами та проектами, 1, 31-36. https://doi.org/10.20998/24133000.2020.1.4

4. Ільганаєва, В. О. (2009). Інформація та знання в інформаційно-комунікаційних процесах. Освіта регіону, 2, 149-152.

5. Симоненко, С. П. (2020). Українська цифрова освіта в умовах цифрової трансформації суспільства: вибір стратегії розвитку. Гілея, 153, 374-377.

6. Цифрова адженда України — 2020 («Цифровий порядок денний» — 2020). Концептуальні засади (версія 1.0). Першочергові сфери, ініціативи, проекти «цифровізації» $\begin{array}{llllll}\text { України до } 2020 & \text { року } & \text { (проект). } & \text { (2016). }\end{array}$ https://ucci.org.ua/uploads/files/58e78ee3c3922.pdf

7. Шейко, В. М. (2001). Культура. Цивілізація. Глобалізація: (кінецьь XIX - початок $X X I \mathrm{~cm}$.$) : монографія. в 2$ т. Харків: Основа.

\title{
DIGITAL STRATEGY AS A COMPONENT OF THE SOCIAL AND COMMUNICATION SPACE OF THE HIGHER EDUCATION INSTITUTION
}

\author{
Olga Bilychenko \\ Dr. of Sciences in Social Communications, the Professor, \\ The Head of the Department of the Ukrainian Language and Literature, \\ SHEI "Donbas State Pedagogical University", \\ Sloviansk, Ukraine \\ ORCID ID 0000-0002-9292-9938 \\ Olgabelichenko64@gmail.com
}

\begin{abstract}
The problem is that in modern socio-cultural conditions, the communication process comes to its greatest importance, which changes the features of the human existence. Scientists note that since the end of the twentieth century, the change in the means of communication has led to such a phenomenon as the globalization of the information process. The analysis of publications shows that the problem of using information and communication (digital) technologies, the creation of a digital educational environment, the digitalization of the educational process have been highlighted in many studies. Nowadays, foreign scientists and those of this country have developed a significant amount of material on the digitization of education. The conceptual problems of informatization and digitalization of education have been developed in numerous scientific investigations of M. Zhaldak, A. Lazarevich, O. Ovcharuk, D. Berry, D. Brett, M. Warsaw, D. Clark, J. Romani. The studies of various aspects of the digital culture as a phenomenon of the information society are reflected in the works of L. Havrilova, I. Eliner, O. Karpenko, S. Chernykh. But it should be marked that the very place of the digital component in the social and communication space of higher education is practically beyond the attention of researchers. The subject of the research is the social and communication space of the higher education.

Accordingly, the research topic is the digital strategy as a component of the social and communication space of the higher education institution. The theme and problem of our study defines the goal - an attempt to prove the necessity to develop a flexible social and communication space focused not so much on the subject matter but on the development of the world of communication relationships in the education system. The results of the study are the following: the social and communication space of a higher education institution can be considered as a kind of the social and communicative space of education in general. The conclusions indicate that in our opinion, the social and communication space of higher education is a complex element of social reality, which has its
\end{abstract}

Професіоналізм педагога: теоретичні й методичні аспекти. Методичні матеріали до проєкту «Цифровий освітній простір: українсько-польський досвід». - Слов’янськ, 2021. 


\section{О. БІЛИЧЕНКО}

Цифрова стратегія як складник соціально-комунікаційного простору закладу вищої освіти

own structure, contains the subjective-objective relations of different levels and has its own information content.

Key words: digitization; higher education; social communications.

\section{REFERENCES}

1. Buryak, V. D. (2010). Communication and Textual Discourse. State and Regions. Series: Social Communications, 3, 4-7.

2. Guzhva, V. M. (2019). Digital Transformation of Universities. Eastern Europe: Economics, Business and Management, 21, 597-604.

3. Yegorchenkova, N. Yu., Tesla, Yu. M., Khlevna, Yu. L., \& Kichan, O. M., (2020). Methodological Aspects of Creating a Digital University. Bulletin of the National Technical University "Kharkiv Polytechnic Institute". Series: Strategic Management, Portfolio Management, Programs and Projects, 1, 31-36. https://doi.org/10.20998/2413- 3000.2020.1.4

4. Ilganaeva, V. O. (2009). Information and Knowledge in Information and Communication Processes. Education of the Region, 2, 149-152.

5. Simonenko, S. P. (2020). Ukrainian Digital Education in the Context of Digital Transformation of Society: the Choice of Development Strategy. Gileya, 153, 374-377.

6. Digital Agenda of Ukraine - 2020. Conceptual Principles (version 1.0). Priority areas, initiatives, projects of "digitalization" of Ukraine until 2020 (project). (2016). Retrieved from https://ucci.org.ua/uploads/files/58e78ee3c3922.pdf

7. Sheiko, V. M. (2001). Culture. Civilization. Globalization: (End of XIX-Beginning of XXI century): monograph. in 2 vols. Kharkiv, Ukraine.

Матеріали надійшли до редакції 21.09.2021 р. 